Пожежна безпека

Fire Safety
ISSN 2078-6662 (print), ISSN 2708-1087 (online)

https://journal.ldubgd.edu.ua/index.php/PB

УДК 614.841

DOI: $10.32447 / 20786662.37 .2020 .08$

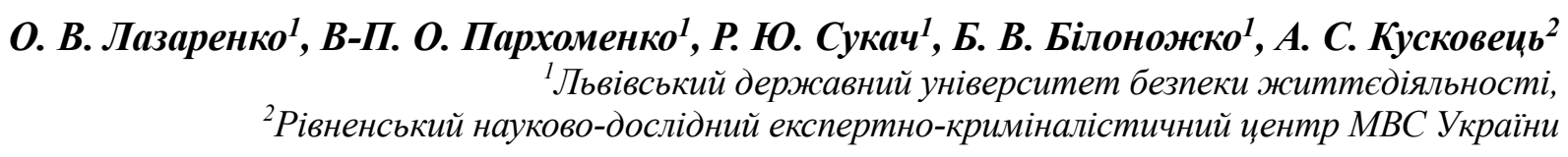

КОНСТРУКТИВНІ ОСОБЛИВОСТІ ТА НЕБЕЗПЕКА АВТОМОБІЛІВ НА ВОДНЕВОМУ ПАЛИВІ

Вступ. Поступовий та невпинний розвиток джерел альтернативної енергії та постійна боротьба людства 3 надлишком викидів парникових газів призвела одночасно й до розвитку транспортних засобів на альтернативних джерелах енергії. Вже сьогодні набувають все більшої популярності транспортні засоби, що працюють виключно на електриці і практично безпечні для екології. Серед різноманіття транспортних засобів, що працюють на електриці, необхідно окремо виділити транспортні засоби, які для отримання електроенергії використовують стиснений водень. Автомобілі на водневому паливі (АВП) вже широко використовуються в США, Німеччині, Японії та інших країнах світу, а уряди країн постійно розширюють та розвивають відповідну інфраструктуру для них.

Мета та задачі дослідження. Проаналізувати базову будову АВП та визначити основні сценарії можливих (НC), а саме: пожежа або вибух паливних резервуарів з воднем; витікання, горіння водню 3 паливопроводів (резервуара) під високим тиском; факельне горіння водню під високим тиском; витікання водню в приміщенні (гараж, закритий паркінг) без подальшого горіння.

Методи. В роботі за результатами літературного огляду визначено імовірні небезпеки для особового складу аварійно-рятувальних підрозділів, задіяних на ліквідацію визначених сценаріїв НС.

Результати. Встановлено, що: під час горіння АВП найбільш імовірне факельне горіння водню (температура полум'я може досягати $2000{ }^{\circ} \mathrm{C}$ ), також можливий вибух балонів з воднем або газоповітряної суміші зі значним радіусом дії; витікання водню в приміщенні може спричинити його руйнування за досить короткий проміжок часу (близько 15 секунд), та/або отруєння (асфіксію) людей внаслідок різкого пониження концентрації кисню.

Висновки. Проведений аналіз та узагальнення знань про потенційну небезпеку АВП, електроавтомобілів дає обгрунтовані підстави стверджувати, що нормативно-правова база щодо будівництва та облаштування систем безпеки наземних та підземних автопаркінгів, місць скупчення подібного автотранспорту не адаптована під реалії сьогодення. Одночасно з тим наступні дослідження повинні бути спрямовані на оцінку імовірних ризиків виникнення подібних надзвичайних ситуацій.

Ключові слова: водень, автомобілі на водневому паливі (АВП), гасіння АВП, небезпека АВП.

O. V. Lazarenko ${ }^{1}$, V-P. O. Parkhomenko ${ }^{1}$, R. Yu. Sukach ${ }^{1}$, B. V. Bilonozhko ${ }^{1}$, A. S. Kuskovets ${ }^{2}$ ${ }^{1}$ Lviv State University of Life Safety, ${ }^{2}$ Rivne Scientific Research Forensic Center Ministry of Interior of Ukraine

\title{
DESIGN FEATURES AND HAZARDS OF HYDROGEN FUEL CELL CARS
}

Introduction. The gradual and relentless development of alternative energy sources and the constant struggle of humanity with excess greenhouse gas emissions led to the simultaneous development of vehicles with alternative energy sources. Currently, vehicles that run exclusively on electricity and are virtually safe for the environment are becoming increasingly popular. Among the variety of vehicles running on electricity, it is necessary to single out vehicles that use compressed hydrogen to generate electricity. Hydrogen fuel cell vehicles (HFCV) are already widely used in the United States, Germany, Japan, and the rest of the world, and their governments are constantly expanding and developing the appropriate infrastructure for them.

The purpose and objectives of the study. The paper analyses the basic structure of HFCV and identifies the main scenarios of possible emergencies, namely: fire or explosion of fuel tanks with hydrogen; leakage, flaming of hydrogen from fuel lines (tank) under the high pressure; high-pressure hydrogen jet fire; leakage of hydrogen in the compartment (garage, closed parking) without further combustion. 
Methods. In the work on the subsequent literature review, the probable dangers for the personnel of the emergency rescue units involved in the elimination of certain emergency scenarios were identified.

Results. It is established that: during the combustion of HFCV the most probable jet fire of hydrogen (flame temperature can reach 2000 0C), and also possible explosion of hydrogen cylinders or gas-air mixture with a significant range. Secondly, leakage of hydrogen in the compartment can cause its destruction in a relatively short period (about 15 seconds), and/or poisoning (asphyxia) of people due to a sharp decrease in oxygen concentration.

Conclusions. The analysis and generalization of existing knowledge on the potential hazard of HFCV is conducted, electric cars give us reasonable grounds to argue that the regulatory framework for the construction and installation of security systems for land and underground parking, places of accumulation of such vehicles is not adapted to today's realities. At the same time, the following studies should be directed at estimating probablee risks of such emergencies.

Keywords: hydrogen fuel cell vehicles (HFCV), HFCV extinguishing, HFCEV hazard.

Вступ. Проведений раніше аналіз небезпеки електроавтомобілів (ЕА), основних його елементів $[1,2]$, тактики та особливостей проведення гасіння EA [3] показав значну проблему сьогодення, а саме неготовність, необізнаність суспільства та оперативно-рятувальних служб до реагування на надзвичайні ситуації (пожежі), пов'язані з транспортними засобами (Т3) на альтернативних джерелах енергії. Черговим доказом вищезазначеного $\epsilon$ встановлення обмежувальних знаків для подібних Т3, наприклад у Королівстві Нідерландів вже перед в їздом в деякі паркінги встановлено подібні знаки рис.1.

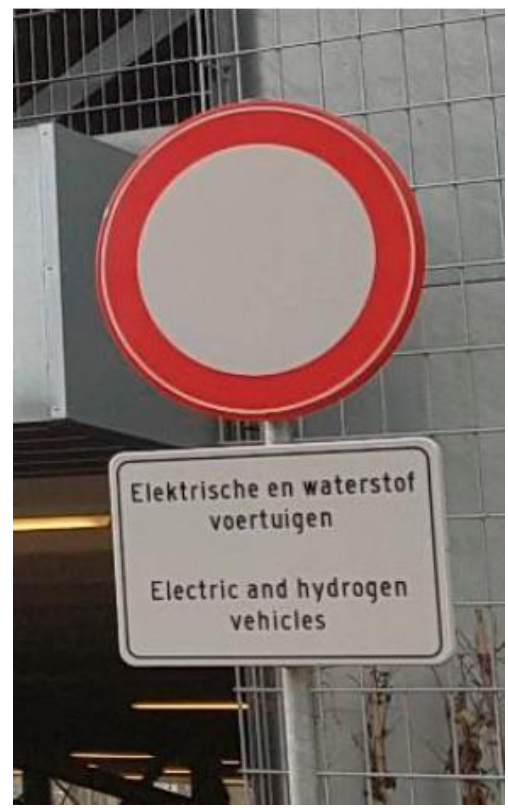

Рисунок 1 - Приклад дорожнього знака, що забороняє заїзд на паркінг автомобілям на альтернативних джерелах енергії

(Королівство Нідерландів)

Однак, не лише ЕА набувають сьогодні все більшої популярності та ширшого застосування. Практично на рівні з ЕА в США, Японії, Німеччині все більше популяризуються автомобілі на водневому паливі АВП, що створює нові та цілком протилежні загрози для рятувальників.

Постановка проблеми. АВП це відносно новий тип електротранспорту який за своєю будовою $\epsilon$ відмінним від звичайних ЕА хоч й має деякі ідентичні конструктивні елементи. Робота АВП базується виключно на запасі стисненого водню $\left(\mathrm{H}_{2}\right)$, що і вирізняє цей ТЗ серед інших ТЗ на альтернативних джерелах енергії. Специфічні властивості водню та його пожежна небезпека потребують особливої уваги зі сторони оперативно-рятувальних підрозділів під час проведення аварійно-рятувальних та інших невідкладних робіт, а також розробку протоколів безпеки, інструкцій щодо його зберігання, транспортування та використання.

Для розробки вищезазначених документів необхідно вивчити та детально ознайомитися 3 типовою будовою АВП і характеристиками основних небезпечних процесів, що можуть виникати під час горіння або пошкодження АВП.

Виклад основного матеріалу. Як зазначалося вище, АВП - це загалом ТЗ, що працює на електриці, однак на відміну від звичайних ЕА для отримання електроенергії тут використовують стиснений водень. Отримання електроенергії відбувається завдяки протіканню електрохімічного процесу між воднем та киснем в спеціальному паливному елементі, який дозволяє це зробити. Загалом типова будова АВП виглядає таким чином (рис.2):

резервуари зі стисненим воднем. Кількість резервуарів може бути різна, зазвичай не менше двох. Робочий тиск резервуарів для зберігання водню розрахований на 70 МПа;

- паливний елемент (3 англ. fuel cell). Спеціальний пристрій, що дає змогу виробляти електроенергію внаслідок протікання електрохімічної реакції між воднем та киснем (з повітря). Внаслідок реакції утворюється електроенергія та водяна пара. Реакція проходить з виділенням теплоти однак максимальна температура, до якої нагрівається паливний елемент, досягає не більше $90{ }^{\circ} \mathrm{C}[4]$;

- трансформатор електроенергії, що здійснює перетворення електроенергії;

- високовольтна акумуляторна батарея для накопичення електроенергії (240В). Зазвичай використовуються літій-іонні акумуляторні батареї, однак зустрічаються й інші. 


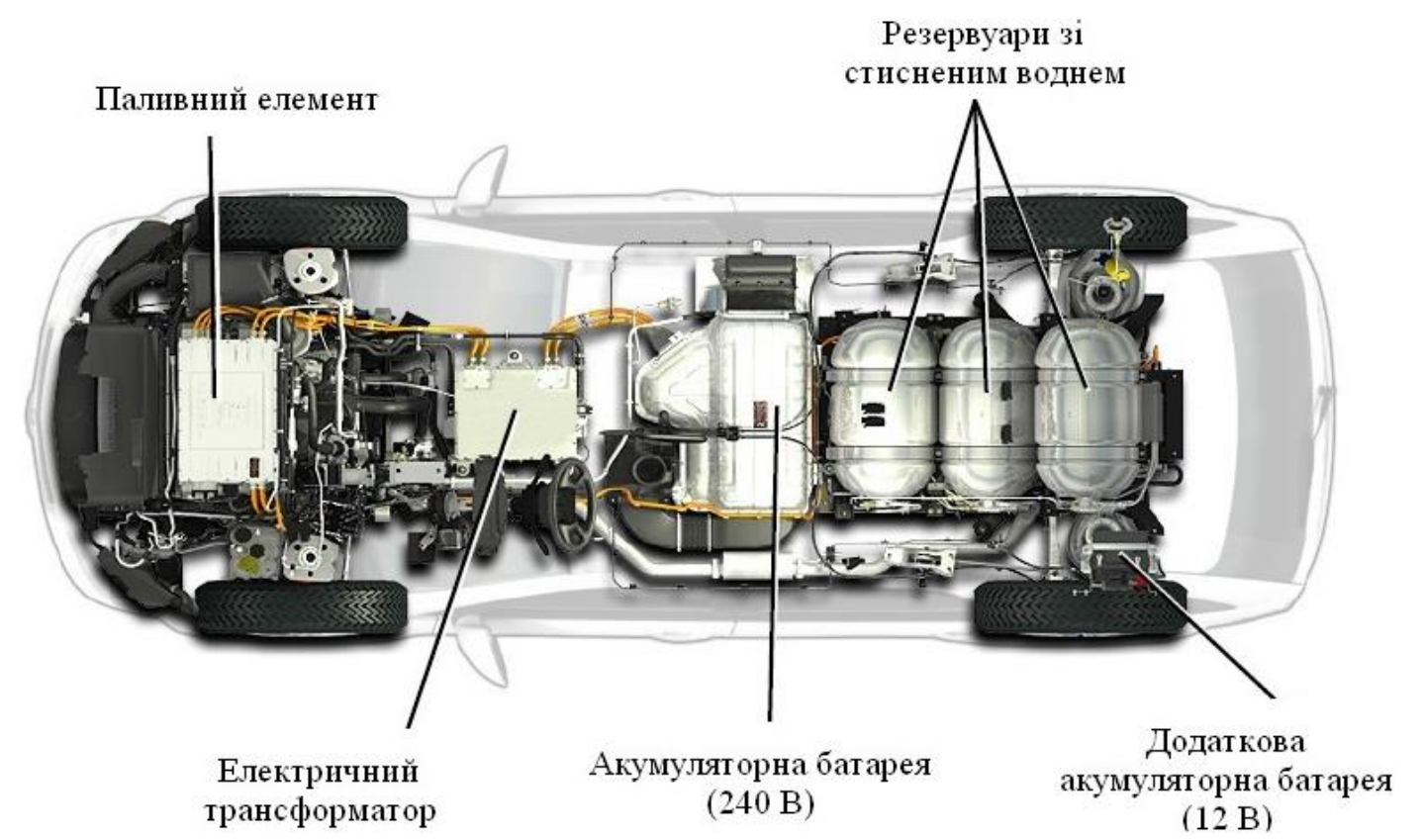

Рисунок 2 - Схема розміщення основних вузлів АВП на прикладі автомобіля Chevrolet Equinox Fuel Cell

3 огляду на представлену будову АВП та грунтуючись на особливостях гасіння та проведення аварійно-рятувальних робіт ЕА можна стверджувати, що наявність акумуляторної батареї великої потужності та електромережі подібного ТЗ потребує ідентичних підходів та алгоритмів роботи рятувальних підрозділів за аналогією з ЕА. Однак, наявність резервуарів зі стисненим воднем під високим тиском 70 МПа та фізичні властивості водню створюють додаткову небезпеку[4].

Основними особливостями водню, 3 точки зору пожежогасіння та пожежної небезпеки, по відношенню до інших, а зокрема вуглеводневих газів, $\epsilon$ :

- температура горіння водню на відкритому повітрі може сягати близько $2000{ }^{\circ} \mathrm{C}$. Водень горить практично безбарвним полум'ям;

- концентрація пароповітряної суміші для гідрогену, що призведе до його подальшого горіння $\epsilon$ вкрай широка від 4 до 75\%, що в порівнянні з іншими горючими газами набагато більше (пропан $2,1-10 \%$, бензин $1-7,8 \%)$. Однак, ключовим параметром $\epsilon$ нижня межа займистості, яка у водню в два рази вища ніж у пропану і в чотири рази - ніж у бензину;

- нижня вибухова межа водню (13-18\%), яка також $\epsilon$ набагато нижчою за концентрації пароповітряних сумішей бензину та інших газів;

- через малу щільність, в'язкість та коефіцієнт дифузії водень здатний витікати практично в три рази швидше ніж інші гази. Для порівняння швидкість витікання водню становить $1308 \mathrm{~m} / \mathrm{c}$, а природного газу $-449 \mathrm{~m} / \mathrm{c}$.

Наведений опис лише деяких основних характеристик водню та все більш зростаюча зацікавленість виробників автомобілів у застосуванні стисненого водню у якості палива для автомобілів без зміни їх конструктивних особливостей дає можливість спрогнозувати такі надзвичайні ситуації, пов' язані з АВП:

- пожежа або вибух паливних резервуарів 3 воднем;

- витікання, горіння водню 3 паливопроводів (резервуара) під високим тиском;

- факельне горіння водню під високим тиском;

- витікання водню в приміщенні (гараж, закритих паркінгів) без подальшого горіння.

Пожежа або вибух паливних резервуарів 3 воднем. Відповідно до властивостей горіння водню, аварійно-рятувальним підрозділам для першочергової ідентифікації імовірного горіння необхідно використовувати для аналізу зображення 3 пожежного тепловізора (рис.3) [5] та газоаналізатори.

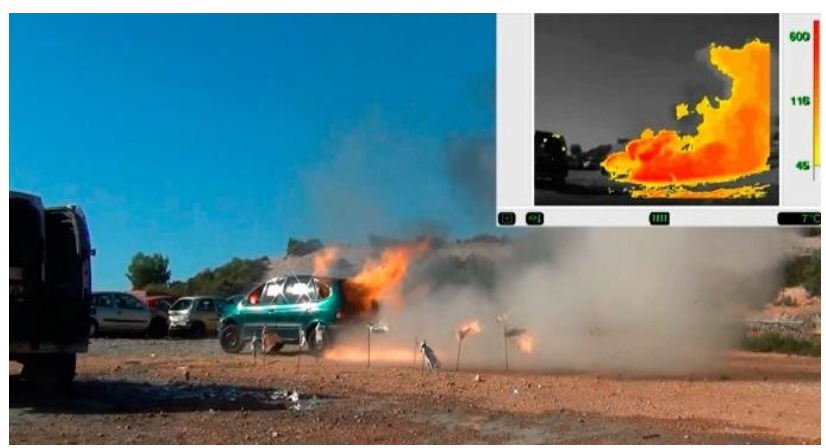

Рисунок 3 - Приклад горіння водню в АВП та його зображення на моніторі пожежного тепловізора

Враховуючи надзвичайно високий тиск зберігання стисненого водню в резервуарах автомобіля оперативно-рятувальні підрозділи повинні враховувати можливість вибуху та руйнівну дію надлишкового тиску, що утворюватиметься внаслідок цього (рис.4). 


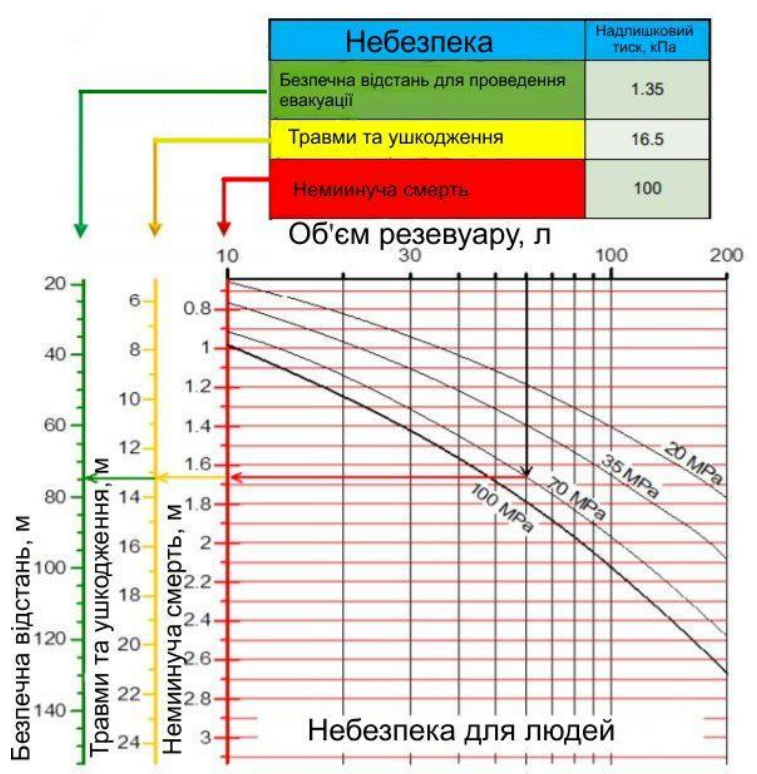

a)

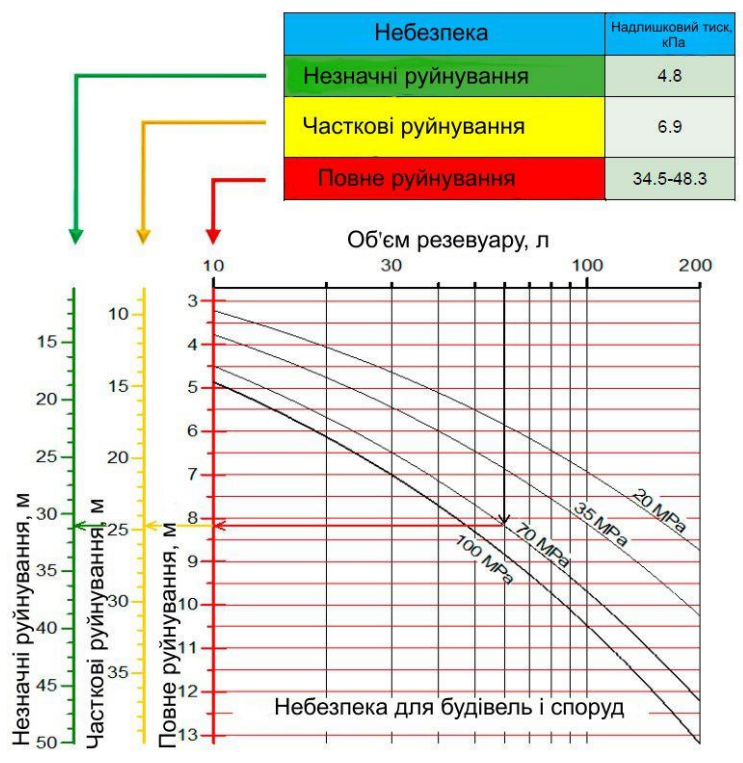

б)

Рисунок 4 - Зони ураження надлишковим тиском вибуху балонів з воднем в АВП (м): а) - небезпека для людини; б) - небезпека для будівель і споруд

Враховуючи показники, наведені на рис.4, керівник гасіння повинен завчасно встановити безпечні межі роботи та перебування цивільних осіб, а за необхідності навіть провести евакуацію 3 прилеглих будівель та споруд.

Витікання водню з паливопроводів (резервуара) під високим тиском. Під час витікання водню під високим тиском (20МПа- 70 МПа) струмінь газу може завдати значних пошкоджень оголеним ділянкам тіла або навіть проникати через захисний одяг. Захисний одяг рятувальника не може на $100 \%$ гарантувати безпеку, згідно з дослідженнями [6] газ під тиском 20 МПа легко проникав через захисні рукавиці та одяг. Проникнення газів через шкірний покрив може призвести до зупинки кровообігу та некрозу тканин [7]. Тиск газу 4,4 МПа достатній, щоб спричинити порізи шкірного покриву людини [8]. Таке явище потрібно братися до уваги рятувальникам під час проведення робіт з ліквідації надзвичайної ситуації, де відбувається витік газу під великим тиском.

Факельне горіння водню під високим тиском. Безпосереднє гасіння подібної пожежі тактично дуже схоже на гасіння газоповітряної суміші (природний газ, пропан-бутан тощо). Найефективнішим методом гасіння буде контрольоване самовигорання водню якщо відсутня небезпека займання сусідніх будівель і споруд. Одночасно з тим, оперативно-рятувальні підрозділи повинні здійснювати охолодження резервуарів 3 воднем та інших елементів ТЗ. Додатковим засобом гасіння подібної пожежі може бути використання спеціальної вогнетривкої кошми [9].

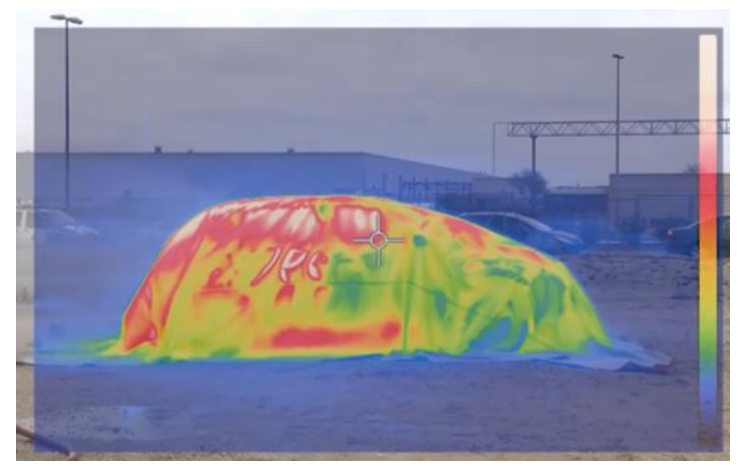

Рисунок 5 - Приклад використання вогнетривкої кошми для гасіння автомобіля

За необхідності наближення особового складу оперативно-рятувальних підрозділів до АВП, що супроводжується факельним горінням необхідно використовувати стволи розпилювачі з високою витратою (рис.6). Прикриваючись розпиленим струменем води (під кутом 150-170) підрозділи здатні наблизитися впритул до ТЗ та провести необхідні дії: перекрити витік водню, збити полум'я з використанням порошкового вогнегасника, провести операцію з гасіння автомобіля з використанням вогнетривкої кошми. 


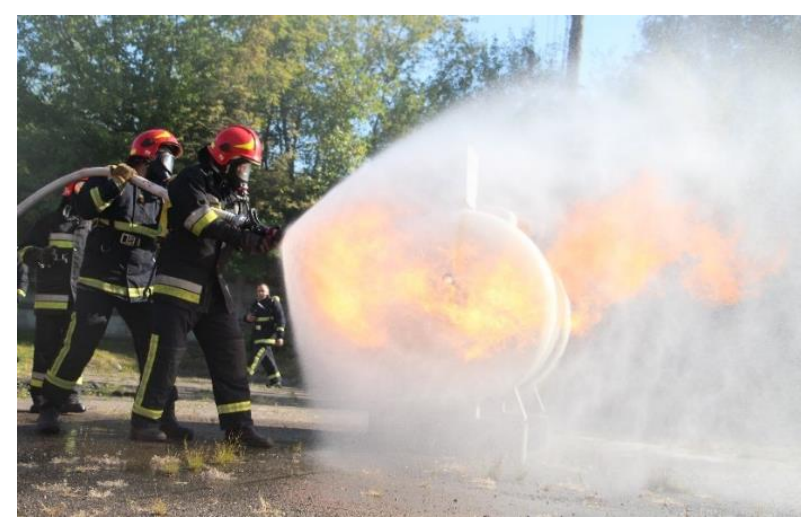

Рисунок 6 - Приклад тактичного використання стволів-розпилювачів для гасіння факельного горіння

Витікання водню в приміщенні. Загалом водень безбарвний газ, який не має запаху та не шкідливий для людини. Однак його швидке виділення та накопичення в обмеженому просторі (приміщенні) може спричинити дефіцит кисню в повітрі, що в свою чергу призведе до втрати свідомості і до смерті людей, що перебувають поблизу. При концентрації кисню в повітрі нижче 19\% людина відчуватиме помітний негативний ефект. Вплив на людину концентрації водню в повітрі та відповідне зниження концентрації кисню вказано в таблиці 1 [6]. Таким чином перед проведення аварійно-рятувальних робіт в приміщеннях 3 АВП особовий склад повинен обов'язково перевірити концентрацію кисню в повітрі та обов'язково бути включеними в захисний дихальний апарат. Одночасно 3 тим необхідно пам'ятати, що при витоках існує загроза виникнення вибуху газоповітряної суміші при досягненні критичних концентрацій, тому використання обладнання, що може спричинити появу іскри необхідно виключити до моменту пересвідчення в повній відсутності небезпечної концентрації водню в повітрі або вентиляції приміщення.

Таблиця 1

\begin{tabular}{|c|c|l|}
\hline $\mathbf{H}_{\mathbf{2}} \%$ & $\mathbf{O}_{\mathbf{2}} \%$ & \multicolumn{1}{|c|}{ Вплив } \\
\hline $0-9$ & $19-21$ & Відсутні симптоми, відносно не шкідливо \\
\hline $9-28$ & $15-19$ & $\begin{array}{l}\text { Зниження уваги та концентрації, незначна за- } \\
\text { дишка }\end{array}$ \\
\hline $28-42$ & $12-15$ & $\begin{array}{l}\text { Пришвидшений пульс, прискорене дихання, по- } \\
\text { гана координація }\end{array}$ \\
\hline $42-52$ & $10-12$ & $\begin{array}{l}\text { Запаморочення, ризик смерті 11\%, час до леталь- } \\
\text { ного ефекту близько 30 хв }\end{array}$ \\
\hline $52-62$ & $8-10$ & $\begin{array}{l}\text { Втрата свідомості, можлива нудота, втрата коль- } \\
\text { ору обличчя, час до летального ефекту близько 5 } \\
\text { хв }\end{array}$ \\
\hline $62-71$ & $6-8$ & $\begin{array}{l}\text { Втрата свідомості за 3 хв, смерть за 8 хв. В 50 \% } \\
\text { випадків смерть, в 50 \% випадків можлива ре- } \\
\text { анімація постраждалого за умови надання допо- } \\
\text { моги впродовж 6 хв, в 100 \% випадків можлива ре- } \\
\text { анімація постраждалого за умови надання допо- } \\
\text { моги впродовж 4-5 хв }\end{array}$ \\
\hline $71-86$ & $3-6$ & $\begin{array}{l}\text { Втрата дихання, серцебиття, кома впродовж 40 с, } \\
\text { пошкодження головного мозку, смерть }\end{array}$ \\
\hline $86-100$ & $0-3$ & \begin{tabular}{l} 
Смерть впродовж 45 с \\
\hline
\end{tabular} \\
\hline
\end{tabular}

Неконтрольоване та швидке витікання водню в приміщенні може спричинити додаткову та не менш загрозливу ситуацію для особового складу та інших мешканців. Зокрема короткочасне та миттєве зростання тиску в приміщенні, що може призвести до його руйнування [10]. Відповідно до системи безпеки резервуарів АВП зі стисненим воднем аварійний термічний клапан для зниження тиску спрацьовує при температурі близько $110^{\circ} \mathrm{C}$. Клапан забезпечує швидке вивільнення водню, таким чином мінімізуючи імовірність вибуху резервуара під час тривалої дії полум'я. Такі умови є досить прийнятними за умови виникнення горіння на свіжому повітрі. Однак небезпека, яка виникає внаслідок швидкого викиду водню в приміщенні, наприклад гаражі, станції технічного обслуговування не прийнятна для забезпечення безпеки та життя оточуючих.

Для прикладу, на рис.7 зображено порівняльну характеристику досягнення максимального тиску в приміщенні (для різних типів газів, зокрема для водню) залежно від часу, за умови однакової швидкості витікання (390 г/c) [11].

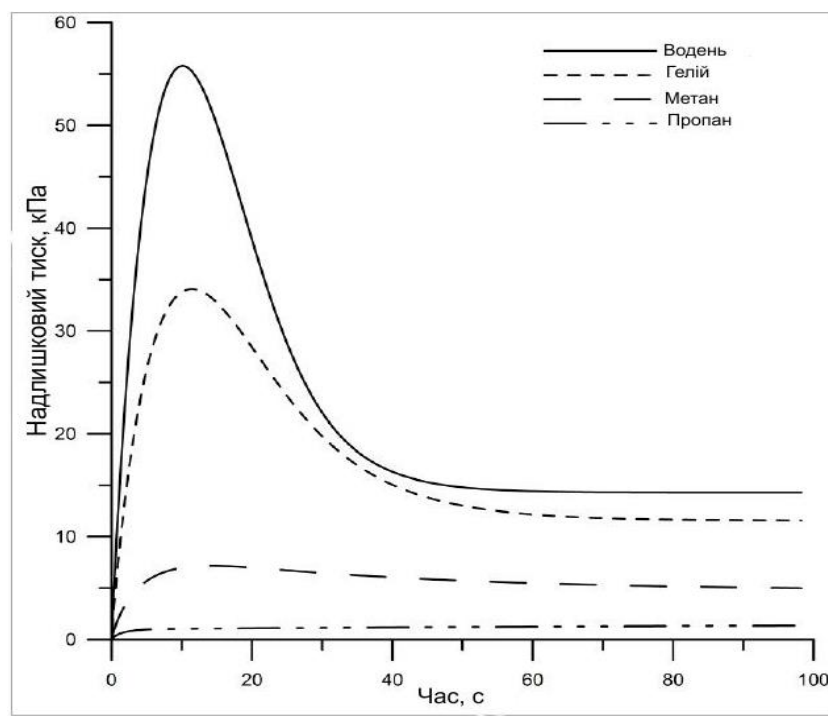

Рисунок 7 - Зображення розподілу тиску в приміщенні об'ємом 30,4 м³ при масовій швидкості витікання 390 г/с для різних типів газів

Відповідно до рис.7 видно, що водень лише за 10-15 секунд часу збільшить тиск в приміщенні до 55 кПа, що призведе до повного руйнування будівлі. Однак, вже за 20 секунд тиск вирівняється до прийнятного в 15 кПа. Цікавим є той факт, що ні для метану ні для пропану не характерна така властивість, а лише гелій має подібну до водню характеристику.

Висновок. Проведений аналіз та узагальнення існуючих знань щодо потенційної небезпеки транспортних засобів на альтернативних джерелах енергії, зокрема електроавтомобілів та автомобілів на водневому паливі, дають обгрунтовані підстави стверджувати, що наступні дослідження повинні бути спрямовані на: 
- розробку національних стандартів, державних будівельних норм стосовно особливостей будівництва та облаштування систем безпеки наземних та підземних автопарковок, місць скупчення подібного автотранспорту;

- внесення змін та/або розробка положень, інструкцій для оперативно-рятувальних підрозділів щодо особливостей гасіння Т3 на альтернативних джерелах живлення;

- аналіз ризиків та імовірності виникнення надзвичайних ситуацій (вибух, займання, тощо) Т3 на альтернативних джерелах живлення.

\section{Список літератури:}

1. Lazarenko O. Research on the Fire Hazards of Cells in Electric Car Batteries / O. Lazarenko, V. Loik, B. Shtain, D. Riegert // Bezpieczeństwo i technika pożarnicza - 2018. - Vol. 52. - Issue 44. - pp.58-67.

2. Ковальчук Т.М. Теоретичні основи гасіння електроавтомобіля / Т.М. Ковальчук, О.В. Лазаренко // XIII Міжнародна науково-практична конференція молодих вчених, курсантів та студентів «Проблеми та перспективи розвитку системи безпеки життєдіяльності»-2018. С. $122-123$.

3. Лазаренко О.В. Пожежогасіння та проведення інших невідкладних робіт в електрокарах / О.В. Лазаренко, О.Д. Синельніков, О.М. Биков, А.С. Биков // Пожежна безпека: зб. наук. пр. - 2019. № 34. - C. 54-58.

4. Frano Barbir Safety issues of hydrogen in vehicles. Режим доступу: https://courses.engr.illinois. edu/npre470/sp2019/web/readings/Hydrogen\%20safety $\% 20$ issues.pdf.

5. Sébastien Bertau D6.3 HYRESPONSE European Emergency Response. Режим доступу: http://www.hyresponse.eu/public_deliverables/ .

6. D. Cirrone Report on hydrogen hazards and risks in tunnels and similar confined spa, 2019. Режим доступу: https://hytunnel.net/wordpress/wp-content/uploads/ 2019/09/HyTunnel-CS_D1.2_Risks-and-Hazards.pdf

7. Lee C. Cadwallader, Haihua Zhao Personnel Safety with Pressurized Gas Systems, 2016. Режим доступу: https://aiche.onlinelibrary.wiley.com/doi/epdf/ 10.1002/prs. 11850

8. A.R. Scott, Occupational high-pressure injection injuries:Pathogenesis and prevention, J Soc Occup Med 33(1983), 56-59.

9. Large fire blanket. Режим доступу: https://www.leader-group.company/en/firefightingequipment/fire-blanket/large-fire-blanket-leader-stop .

10. Molkov, V Fundamentals of Hydrogen Safety Engineering, 2012. Режим доступу: https:/www.arma.org.au/wp-content/uploads/2017/03/ fundamentals-of-hydrogen-safety-engineering-i.pdf
11. Brennan, S., Molkov, V. Safety assessment of unignited hydrogen discharge from onboard storage in garages with low levels of natural ventilation. International Journal of Hydrogen Energy, 2013, 38(19), 81598166.

\section{References:}

1. Lazarenko O., Loik V., Shtain B., Riegert D. (2018) Research on the Fire Hazards of Cells in Electric Car Batteries. Bezpieczeństwo i technika pożarnicza. BITP. Vol. 52. (Issue 44), pp.58-67. doi:10.12845/bitp.52.4.2018.7

2. Kovalchuk T.M., Lazarenko O.V. (2018) Teoretychni osnovy hasinnia elektroavtomobilia [Theoretical foundations of electric car extinguishing]. XIII Mizhnarodna naukovo-praktychna konferentsiia molodykh vchenykh, kursantiv ta studentiv «Problemy ta perspektyvy rozvytku systemy bezpeky zhyttiediialnosti. pp. $122-123$.

3. Lazarenko O.V., O. D. Synelnikov, I. M. Bykov, A. S. Kuskovets (2019) Pozhezhohasinnia ta provedennia inshykh nevidkladnykh robit v elektrokarakh [Fire extinguishing and other urgent work in electric cars] Fire safety Vol 34, pp 54-58.

4. Frano Barbir Safety issues of hydrogen in vehicles. Source: https:/courses.engr.illinois.edu/npre470/ sp2019/web/readings/Hydrogen\%20safety\%20issues.pdf

5. Sébastien Bertau D6.3 HYRESPONSE European Emergency Response. Source:: http://www.hyresponse.eu/public_deliverables/

6. D. Cirrone (2019) Report on hydrogen hazards and risks in tunnels and similar confined spa. Source: https:/hytunnel.net/wordpress/wp-content/uploads/2019/ 09/HyTunnel-CS_D1.2_Risks-and-Hazards.pdf

7. Lee C. Cadwallader, Haihua Zhao (2016) Personnel Safety with Pressurized Gas Systems. Source:https://aiche.onlinelibrary.wiley.com/doi/epdf/10.1002/prs. 11850

8. A.R. Scott, Occupational high-pressure injection injuries: Pathogenesis and prevention, J Soc Occup Med 33(1983), 56-59.

9. Large fire blanket. Source: https://www.leadergroup.company/en/firefighting-equipment/fire-blanket/large-fire-blanket-leader-stop

10. Molkov, V (2012) Fundamentals of Hydrogen Safety Engineering. Source: https://www.arma.org.au/ wp-content/uploads/2017/03/fundamentals-of-hydrogensafety-engineering-i.pdf

11. Brennan, S., Molkov, V. (2013) Safety assessment of unignited hydrogen discharge from on board storage in garages with low levels of natural ventilation. International Journal of Hydrogen Energy, 38(19), 81598166.

\section{* Оглядова стаття}

